\title{
Maternal outcome in preterm labor in a tertiary care hospital
}

\author{
Preeti Frank Lewis, Ayushi Kumari*, Nitin Bavdekar
}

Department of Obstetrics and Gynecology, Grant Government Medical College, Mumbai, Maharashtra, India

Received: 08 October 2020

Revised: 16 November 2020

Accepted: 02 December 2020

\section{*Correspondence:}

Dr. Ayushi Kumari,

E-mail: ayushikum@gmail.com

Copyright: (C) the author(s), publisher and licensee Medip Academy. This is an open-access article distributed under the terms of the Creative Commons Attribution Non-Commercial License, which permits unrestricted non-commercial use, distribution, and reproduction in any medium, provided the original work is properly cited.

\begin{abstract}
Background: To study the fetal and maternal outcome in preterm labor cases.

Methods: It was Prospective, single centered, observational study. All women with preterm labor in the study period i.e. from September 2018 to March 2020 were included in the study i.e. 100 patients.

Results: Out of 100 subjects, majority of mothers 65(65\%) were in age group of 21-30 years followed by 23 (23\%) in age group of $\leq 20$ years. Majority $52(52 \%)$ of study subjects were primigravida followed by $28(28 \%)$ having parity 1 . Only one case had parity 4. Majority $36(36 \%)$ of study subjects were in lower class followed by $28(28 \%)$ cases in lower middle class. $23(23 \%)$ cases in middle class and $6(6 \%)$ were in upper class. Maximum $61(61 \%)$ cases were unbooked cases and rest $39(39 \%)$ cases were booked. Out of 90 babies who were <2500 grams, maximum 57 $(63.33 \%)$ were low birth weight (less than $2.5 \mathrm{~kg}$ ) followed by $22(24.44 \%$ ) being VLBW babies. 10 cases were $\geq 2.5$ $\mathrm{kg}$, which are not LBW babies according to WHO Classification of low birth weight. Majority 34 (47.22\%) stayed for 1-10 days followed by 17 (23.61\%) babies for 11-20 days. Also 15 (20.83\%) babies stayed for 21-30 days.

Conclusions: Compared with term infants, preterm infants are at high risk of overall morbidity and mortality. Clinical suspicion, early detection and correction of risk factors, institutional delivery and good neonatal care back up facilities can improve the outcome of preterm labour and decrease the maternal complications as well.
\end{abstract}

Keywords: Feto maternal outcome, Preterm labour

\section{INTRODUCTION}

WHO defines preterm birth as babies born alive before 37 weeks of pregnancy is completed. It is the leading cause of death worldwide for children below 5 years of age. Many preterm babies survive in high-income countries but in low- and middle-income countries a lack of adequate newborn care puts the lives of many preterm babies at risk. ${ }^{1}$

Preterm labor is one of the syndromes characterized by premature activation of final path way of parturition. Preterm labor may either be a physiological process that has occurred too soon or pathological process following an abnormal stimulus. The etiology of preterm labor may be multi-factorial. The earlier the onset of labor the more likely is that a pathological process is implicated. ${ }^{2}$ Premature babies are at risk of many immediate and longterm complications. Immediate (short term) neonatal morbidity includes respiratory distress syndrome, hypothermia, hypoglycemia, jaundice, intraventricular hemorrhage, necrotizing enterocolitis, bronchopulmonary dysplasia, sepsis and patent ductus arteriosus. Long term morbidity includes cerebral palsy, mental retardation and retinopathy of prematurity. Residual mental and motor handicaps are the major deterrents to the optimal development of preterm infant. ${ }^{2}$

\section{METHODS}

It was prospective, single centered, observational study. All women with preterm labor in the study period i.e. 
from September 2018 to March 2020 were included in the study with the following criteria gestational age between 28 to 36 weeks, singleton pregnancy, with intact membrane. In preterm labor with regular uterine contractions at least 3 every 10 minutes, associated with cervical dilatation of at least $1 \mathrm{~cm}$ but not more than $3 \mathrm{~cm}$ and cervical effacement less than or equal to $50 \%$, Maternal age $>18$ years, married mothers and Non medico-legal pregnancy. Patients with premature rupture of membranes, preeclampsia, malpresentations, fetal malformations, polyhydramnios, placenta previa and abruptio placentae, severe anemia, intrauterine fetal death, intrauterine growth restriction, Rh isoimmunization and uterine and cervical anomalies were all excluded from the study.

\section{Statistical analysis}

The data was entered in Microsoft Excel sheet and Epi Info software SPSS version 25 and EPI Info version 7.3 was used for analysis, incidence and prevalence of fetomaternal outcome, demographic, clinical characteristics of pre-term labor were studied.

\section{RESULTS}

Out of 100 subjects, majority of mothers $65(65 \%)$ were in age group of 21-30 years followed by $23(23 \%)$ in age group of $\leq 20$ years. Mean age was $24.81 \pm 4.49$ ranging from 19 to 37 years. Majority $36(36 \%)$ subjects were in lower class followed by $28(28 \%)$ cases in lower middle class. $23(23 \%)$ cases in middle class and $6(6 \%)$ were in upper class. Maximum $61(61 \%)$ cases were unbooked cases and rest 39 (39\%) cases were booked. Out of 90 babies who were $<2500$ grams, maximum $57(63.33 \%)$ were low birth weight followed by $22(24.44 \%)$ being VLBW babies. 10 cases were $\geq 2.5 \mathrm{kgs}$, which are not LBW babies according to WHO Classification of low birth weight. Majority (30) mothers had lactation insufficiency followed by Puerperal sepsis in 24 mothers. Also, 12 mothers had birth canal trauma cervix, vagina and perineum and 8 mothers had post-partum depression and psychosis. Many mothers had more than one complication. Most common complication being lactation insufficiency followed by puerperal sepsis with or without puerperal pyrexia. Out of 100 babies, newborn jaundice was seen in 66 babies followed by Immune system problems in 32 babies. Metabolism acidosis, inborn metabolic error and hypoglycemia was seen in 20 babies. Many babies had multiple complications. Birth asphyxia and respiratory distress was seen in 18 babies. Out of 72 babies who stayed in NICU, 47 were immediately shifted after birth due to low birth weight and remaining 25 were shifted from mother mostly due to jaundice. Majority 34 (47.22\%) stayed for 1-10 days followed by 17 (23.61\%) babies for 11-20 days. Also 15 (20.83\%) babies stayed for 21-30 days. Only 06 (8.34\%) babies stayed for $>30$ days in NICU. Out of 36 total neonatal deaths, maximum $10(27.78 \%)$ babies died due to sepsis followed by $08(22.22 \%)$ due to birth asphyxia.
Out of 36 deaths that occurred, majority i.e. $14(38.89 \%)$ occurred within 3-8 days followed by 12 (33.33\%) deaths within 9-14 days.

Table 1: Distribution of preterm cases according to age groups.

\begin{tabular}{|lll|}
\hline Age group (in years) & Number & Percentage \\
\hline$\leq \mathbf{2 0}$ & 23 & 23 \\
\hline $\mathbf{2 1 - 3 0}$ & 65 & 65 \\
\hline $\mathbf{3 1 - 4 0}$ & 11 & 11 \\
\hline Total & 100 & 100 \\
\hline
\end{tabular}

Table 1 shows distribution of preterm cases according to age. Out of 100 subjects, majority of mothers $65(65 \%)$ were in age group of 21-30 years followed by 23 (23\%) in age group of $\leq 20$ years. Mean age was $24.81 \pm 4.49$ ranging from 19 to 37 years.

Table 2: Distribution of preterm cases according to parity.

\begin{tabular}{|lll|}
\hline Parity & Number & Percentage \\
\hline Primigravida & 52 & 52 \\
\hline P1 & 28 & 28 \\
\hline P2 & 13 & 13 \\
\hline P3 & 6 & 6 \\
\hline P4 & 1 & 1 \\
\hline Total & 100 & 100 \\
\hline
\end{tabular}

Table 2 shows distribution of preterm cases according to parity. Majority $52(52 \%)$ of study subjects were primigravida followed by $28(28 \%)$ having parity. This was followed by $13(13 \%)$ having parity 2 . Only one case had parity 4 .

\section{Table 3: Distribution of pre-term cases according to socioeconomic status according to modified Kuppuswamy scale classification.}

\begin{tabular}{|lll|}
\hline Socioeconomic class & Number & Percentage \\
\hline V (lower class) & 36 & 36 \\
\hline IV (lower middle) & 28 & 28 \\
\hline III (middle class) & 23 & 23 \\
\hline II (upper middle) & 7 & 7 \\
\hline I (upper class) & 6 & 6 \\
\hline Total & 100 & 100 \\
\hline
\end{tabular}

Table 4: Distribution of pre-term cases according to registration of case.

\begin{tabular}{|lll|}
\hline Type of case & Number & Percentage \\
\hline Booked & 39 & 39 \\
\hline Unbooked & 61 & 61 \\
\hline Total & 100 & 100 \\
\hline
\end{tabular}

Table 3 shows distribution of pre-term cases according to socioeconomic status according to modified 
Kuppuswamy scale classification. Majority 36 (36\%) subjects were in lower class followed by $28(28 \%)$ cases in lower middle class. $23(23 \%)$ cases in middle class and $6(6 \%)$ were in upper class.

Table 4 shows distribution of pre-term cases according to registration of case. Maximum $61(61 \%)$ cases were unbooked cases and rest $39(39 \%)$ cases were booked.

Table 5: Distribution of babies of preterm cases according to WHO Classification of low birth weight.

\begin{tabular}{|lll|}
$\begin{array}{l}\text { WHO classification of low } \\
\text { birth weight (in grams) }\end{array}$ & Number & Percentage \\
\hline$\leq \mathbf{1 0 0 0}$ (ELBW) & 11 & 12.22 \\
\hline $\mathbf{1 0 0 1 - 1 5 0 0}(\mathbf{V L B W})$ & 22 & 24.44 \\
\hline $\mathbf{1 5 0 1 - < 2 5 0 0}$ (LBW) & 57 & 63.33 \\
\hline Total & 90 & 100 \\
\hline
\end{tabular}

*ELBW: Extremely low birth weight; *VLBW: Very low birth weight; *LBW: low birth weight; 10 cases were of weight $\geq 2500$ gms.

Table 5 shows distribution of babies of preterm cases according to WHO classification of low birth weight. Out of 90 babies who were $<2500$ grams, maximum 57 $(63.33 \%)$ were low birth weight followed by $22(24.44 \%)$ being VLBW babies. 10 cases were $\geq 2.5 \mathrm{kgs}$, which are not LBW babies according to WHO Classification of low birth weight.

Table 6: Distribution of pre-term cases according to postnatal complications.

\begin{tabular}{|ll|}
\hline Postnatal complications & Number \\
\hline Absent & 34 \\
\hline Present & $\mathrm{N}=66$ \\
\hline Lactation insufficiency & 30 \\
\hline Puerperal sepsis & 24 \\
\hline $\begin{array}{l}\text { Birth canal trauma - cervix, vagina and } \\
\text { perineum }\end{array}$ & 12 \\
\hline Post-partum hemorrhage & 10 \\
\hline Retained placenta & 4 \\
\hline Episiotomy gape & 8 \\
\hline Post-partum psychosis and depression & 8 \\
\hline
\end{tabular}

Table 6 shows distribution of pre-term cases according to postnatal complications. Out of 100 cases, 66 cases had postnatal complications. Majority (30) mothers had lactation insufficiency followed by Puerperal sepsis in 24 mothers. Also, 12 mothers had birth canal trauma cervix, vagina and perineum and 8 mothers had postpartum depression and psychosis. Many mothers had more than one complication. Most common complication being lactation insufficiency followed by puerperal sepsis with or without puerperal pyrexia.

Table 7 shows distribution of babies of pre-term cases according to complications. Out of 100 babies, newborn jaundice was seen in 66 babies followed by Immune system problems in 32 babies. Metabolism acidosis, inborn metabolic error and hypoglycemia was seen in 20 babies. Many babies had multiple complications. Birth asphyxia and respiratory distress was seen in 18 babies.

Table 7: Distribution of babies of pre-term cases according to complications.

\begin{tabular}{|ll|}
\hline Fetal complications & Number \\
\hline Newborn jaundice & 66 \\
\hline Immune system problems & 32 \\
\hline Metabolism acidosis & 20 \\
\hline Inborn metabolic error & \\
\hline Hypoglycemia & 18 \\
\hline Birth asphyxia & 16 \\
\hline Respiratory distress & 16 \\
\hline Anemia/Thrombocytopenia & 14 \\
\hline Hypothermia & \\
\hline Necrotizing enterocolitis & 14 \\
\hline Hypoxic ischemic encephalopathy & \\
\hline Meningitis & 12 \\
\hline Seizure disorders & 4 \\
\hline PDA/ASD/VSD &
\end{tabular}

Table 8: Distribution of babies of pre term cases according to duration of NICU stay.

\begin{tabular}{|lll|}
\hline Duration of stay (in days) & Number & Percentage \\
\hline 01-10 & 34 & 47.22 \\
\hline $\mathbf{1 1 - 2 0}$ & 17 & 23.61 \\
\hline $\mathbf{2 1 - 3 0}$ & 15 & 20.83 \\
\hline $\mathbf{3 0}$ & 6 & 8.34 \\
\hline Total & 72 & 100 \\
\hline
\end{tabular}

Table 8 shows distribution of babies of pre-term cases according to duration of NICU stay. Out of 72 babies who stayed in NICU, 47 were immediately shifted after birth due to low birth weight and remaining 25 were shifted from mother mostly due to jaundice. Majority 34 (47.22\%) stayed for 1-10 days followed by 17 (23.61\%) babies for 11-20 days. Also $15(20.83 \%)$ babies stayed for 21-30 days. Only $06(8.34 \%)$ babies stayed for $>30$ days in NICU.

Table 9: Distribution of neonates of pre term cases according to cause of death.

\begin{tabular}{|lll|}
\hline Cause of death & Number $\mathbf{N = 3 6}$ & Percentage \\
\hline Sepsis & 10 & 27.78 \\
\hline Birth asphyxia & 8 & 22.22 \\
\hline Respiratory distress & 7 & 19.44 \\
\hline Metabolic disorders & 5 & 13.89 \\
\hline Neonatal jaundice & 6 & 16.67 \\
\hline Total & 36 & 100 \\
\hline
\end{tabular}

Table 9 shows distribution of babies of pre-term cases according to cause of death. Out of 36 total neonatal 
deaths, maximum $10(27.78 \%)$ babies died due to sepsis followed by $08(22.22 \%)$ due to birth asphyxia.

Table 10: Distribution of babies of pre-term cases according to duration in which neonatal deaths occurred.

\begin{tabular}{|lll|}
\hline $\begin{array}{l}\text { Duration of NND within } \\
\text { (in days) }\end{array}$ & Number & Percentage \\
\hline$\leq \mathbf{2}$ & 10 & 27.78 \\
\hline $\mathbf{0 3 - 8}$ & 14 & 38.89 \\
\hline $\mathbf{9 - 1 4}$ & 12 & 33.33 \\
\hline Total & 36 & 100 \\
\hline
\end{tabular}

Table 10 shows distribution of babies of pre-term cases according to duration in which neonatal deaths occurred. Out of 36 deaths that occurred, majority i.e. 14 (38.89\%) occurred within 3-8 days followed by 12 (33.33\%) deaths within 9-14 days.

\section{DISCUSSION}

The present study was carried out in Obstetrics and Gynaecology department of our institute. We included 100 cases of mothers with preterm labor and 100 mothers with term labor as a comparison group. Out of 100 preterm cases, 98 cases were vaginal deliveries and only 2 were lower segment cesarean section (LSCS).

\section{Age incidence}

In present study, majority of cases $65(65 \%)$ were in age group of 21-30 years followed by $23(23 \%)$ in age group of $\leq 20$ years. Mean age was $24.81 \pm 4.49$ ranging from 19 to 37 years. There was no significant association between maternal age and Feto-maternal outcome in present study.

In similar study by Dingens et al from USA, majority (29\%) of mothers from preterm group were in age group of $20-25$ years. Lakshmi et al from Telangana observed majority of the women in both groups of preterm and term labor were between 20-29 years which is similar to present study. Philip et al from Kerala, India in their study on neonatal outcome of preterm births found no significant association of the maternal age to the neonatal outcome in preterm births in present study which is similar to present study. Following table shows mean age in different studies. ${ }^{3-5}$

\section{Parity}

In present study, majority $52(52 \%)$ of study subjects were primigravida followed by $28(28 \%)$ having parity 1 . This was followed by $13(13 \%)$ having parity 2 . Only one case had parity 4 . Out of 60 cases of bacterial vaginosis, maximum $36(60 \%)$ cases were primigravida followed by $14(23.33 \%)$ cases with parity 1 . Derakhshi et al observed double or multiples pregnancies most common in their study, Palomer et al in their study observed $19.2 \%$ of preterm newborns related to the multiple pregnancies, Mohsenzadeh et al in their study observed $19.7 \%$ of premature newborns were due to multiple pregnancies which is not consistent with our study. ${ }^{15-17}$

\section{Socioeconomic status}

In present study, majority $36(36 \%)$ of mothers belonged to lower class followed by $28(28 \%)$ cases in lower middle class. The mothers with lower socioeconomic status were more in BV positive category as compared to $\mathrm{BV}$ negative patients.

A study by Ali et al from Assam observed that socioeconomic status was found be lower in BV positive patients as compared to $\mathrm{BV}$ negative patients which is consistent with present study. ${ }^{18}$ Another study by Jain et al found that preterm labor was more common lower socioeconomic class $(58 \%)$ which is higher than present study. ${ }^{19}$ Lata et al found more mothers in lower class with $\mathrm{BV}$ positive as compared to other socioeconomic classes and this is similar to present study. ${ }^{8}$

\section{Birth weight}

In present study, majority 57 (57\%) babies were having weight $<2 \mathrm{kgs}$ followed by $32(32 \%)$ babies having weight between 2-2.4 kgs. The combined low birth weight accounts for $90(90 \%)$ babies. This is higher as compared to other similar studies as present study had most of deliveries between 32-35 weeks of gestation. Akhter et al in their study on perinatal outcome in preterm labor found $42 \%$ of low birth babies in preterm group which is lower than present study. ${ }^{2}$ Laxmi et al found that LBW was present in $33.3 \%$ of the women in the study group (preterm mothers) and $3.33 \%$ in the control group (term mothers). This finding is lower than present study. ${ }^{4}$ Seth et al observed that $20 \%$ babies were LBW in preterm group of women which is lower than present study. ${ }^{20}$

Henderson et al discussed that almost $57 \%$ of babies were LBW in mothers with gestational period of $<37$ weeks which is similar finding as present study but the percentage is lower than present study findings. ${ }^{21}$

\section{Post-natal complications}

Out of 100 cases, $66(66 \%)$ cases had postnatal complications and 34 had no complications. Majority (30) mothers had lactation insufficiency followed by Puerperal sepsis in 24 mothers. 12 mothers had birth canal trauma cervix, vagina and perineum and 8 mothers had post-partum depression and psychosis. Also, out of 60 mothers with presence of bacterial vaginosis, maximum 45 (75\%) mothers had post-natal complications. Merrikay et al in an economic model discussed that series of studies reviewed for the incidence and attributable risks of pregnancy complications related to $\mathrm{BV}$ included women from different ethnic and 
socioeconomic groups reported an increased risk for preterm delivery or LBW among women with BV. This finding is consistent with present study.

Jiang et al observed that cases with scarred uterus, women who had cesarean section once or more or other previous uterine surgery, occurred in both control and preterm pregnancies, but were significantly increased in the latter which is consistent with present study. Women with placenta previa or abnormal S/D ratio were more likely to have preterm delivery.

\section{NICU stay and admission}

In present study, out of 100 babies, $72(72 \%)$ babies who stayed in NICU, majority 11 (34.38\%) stayed for 21-30 days followed by $9(28.12 \%)$ babies for 1-10 days. Henderson et al in their study observed that women with gestational age of $32-36$ weeks had $62.4 \%$ of babies admitted in NICU which is lower than present study. ${ }^{21}$

Laxmi et al in their comparative study on preterm and term labor found $43.33 \%$ babies from preterm group with NICU admission which is lower than present study. NICU stay more than 2 days was seen in $43.33 \%$ babies in preterm group which is higher than present study findings of $28.12 \% .^{4}$

\section{Neonatal deaths}

In present study, out of $36(36 \%)$ total neonatal deaths. Maximum $10(27.78 \%)$ babies died due to sepsis followed by $08(22.22 \%)$ due to birth asphyxia. Respiratory distress was cause of death in seen in 07 (19.44\%) neonates. Out of 36 total neonatal deaths, 21 had mothers with bacterial vaginosis. Out of these 21 mothers, majority $06(28.57 \%)$ had neonates who died due to sepsis.

Akhter et al found 35\% neonatal deaths in preterm labor group which similar to present study findings. Respiratory distress was most common cause of NICU admission and mortality which is similar to present study whereas Laxmi et al discussed $20 \%$ neonatal deaths in their study which is lower than present study. ${ }^{2,25}$

Bangal et al found that neonatal mortality was $100 \%$ in the babies born with birth weight of 1000 grams. Neonatal mortality was directly proportional to birth weight of the baby. Neonatal mortality was $63.33 \%$ in babies born before 31 weeks of gestation. Overall early neonatal mortality was $27.27 \%$. Sepsis, respiratory distress and birth asphyxia was most common cause of NICU admission and mortality which is similar to present study. ${ }^{25}$

Singh et al found that septicemia and hypoxic ischemic encephalopathy were the two most common causes of neonatal morbidity and mortality after RDS, accounting for $16.8 \%$ and $9.2 \%$ respectively in less than 34 weeks gestational age group. ${ }^{22}$ Hyperbilirubinemia developed in approximately $50 \%$ of preterm babies irrespective of gestational age which is higher than present study.

\section{Limitations}

Single center observational study with a small sample size.

\section{CONCLUSION}

The present study is an attempt to obtain data in pattern of early neonatal morbidity and mortality to compare it with term neonates. There is a particular need to educate health care providers and parents about the vulnerability of infants born between 28-36 weeks of gestation. From the present study and the literature, it is clear that preterm group is significantly more vulnerable when compared with the term group. This study will lead to review of care for preterm group and help optimize care for this cohort of infants.

Reorganization of services and increased resource allocation to provide better clinical support to this group may be needed in most settings. The findings of this study may also affect antenatal counselling regarding delivery in preterm gestation.

Understanding morbidity risk among preterm infants is not only important helping new-born care providers to anticipate and to manage potential morbidity during birth hospitalization and earlier follow up after hospital discharge, but also may possibly assist in guiding nonemergency obstetric intervention decisions.

\section{Funding: No funding sources \\ Conflict of interest: None declared}

Ethical approval: The study was approved by the Institutional Ethics Committee

\section{REFERENCES}

1. WHO | Care of the preterm and/or low-birth-weight newborn. WHO. 2014;

2. Akhter G, Rizvi SM, Hussain SI. Evaluation of perinatal outcome in preterm labour. Sch Int J Obstet Gynec. 2020;3(6):147-52.

3. Dingens AS, Fairfortune TS, Reed S, Mitchell C. Bacterial vaginosis and adverse outcomes among full-term infants: a cohort study. BMC Pregnancy Childbirth. 2016;16(1):1-8.

4. Laxmi U, Agrawal S, Raghunandan C, Randhawa VS, Saili A. Association of bacterial vaginosis with adverse fetomaternal outcome in women with spontaneous preterm labor: a prospective cohort study. J Matern Neonatal Med. 2012;25(1):64-7.

5. Philip T, Thomas P. A prospective study on neonatal outcome of preterm births and associated factors in a South Indian tertiary hospital setting. Int J Reprod Contraception Obstet Gynecol. 2018;7(12):4827. 
6. Clark P, Kurtzer T, Duff P. Role of bacterial vaginosis in peripartum infections. Infect Dis Obstet Gynecol. 1994;2(4):179-83.

7. Joesoef MR, Hillier SL, Wiknjosastro G, Sumapouw $\mathrm{H}$, Linnan $\mathrm{M}$, Norojono $\mathrm{W}$, et al. Intravaginal clindamycin treatment for bacterial vaginosis: Effects on preterm delivery and low birth weight. Am J Obstet Gynecol. 1995;173(5):1527-31.

8. Lata I, Pradeep Y, Sujata S, Jain A. Estimation of the incidence of bacterial vaginosis and other vaginal infections and its consequences on maternal/fetal outcome in pregnant women attending an antenatal clinic in a tertiary care hospital in North India. Indian J Community Med. 2010;35(2):285-9.

9. Dingens AS, Fairfortune TS, Reed S, Mitchell C. Bacterial vaginosis and adverse outcomes among full-term infants: A cohort study. BMC Pregnancy Childbirth. 2016;16(1):1-8.

10. Aderoba A, Olokor O, Olagbuji B, Ande A, Okonkwo C, Ojide C. Bacterial vaginosis in spontaneous preterm and term birth: a case-control study. Trop J Obstet Gynaecol. 2016;33(3):297.

11. Philip T, Thomas P. A prospective study on neonatal outcome of preterm births and associated factors in a South Indian tertiary hospital setting. Int $\mathrm{J}$ Reprod Contraception Obstet Gynecol. 2018;7(12):4827.

12. Jiang M, Mishu MM, Lu D, Yin X. A case control study of risk factors and neonatal outcomes of preterm birth. Taiwan J Obstet Gynecol. 2018;57(6):814-8.

13. Soltani M, Tabatabaee HR, Saeidinejat S, Eslahi M, Yaghoobi H, Mazloumi E, et al. Assessing the risk factors before pregnancy of preterm births in Iran: A population-based case-control study. BMC Pregnancy Childbirth. 2019;19(1):1-8.

14. Kamga YM, Ngunde JP, Akoachere JFKT. Prevalence of bacterial vaginosis and associated risk factors in pregnant women receiving antenatal care at the Kumba Health District (KHD), Cameroon. BMC Pregnancy Childbirth. 2019;19(1):1-8.

15. Derakhshi B, Esmailnasab N, Ghaderi E, HemMatpour S. Risk factor of preterm labor in the west of Iran: a case-control study. Iran J Public Health. 2014;43(4):499-506.

16. Palomar L, DeFranco EA, Lee KA, Allsworth JE, Muglia LJ. Paternal race is a risk factor for preterm birth. Am J Obstet Gynecol. 2007;197(2):152-7.

17. Mohsenzadeh A, Saket S, Karim A. Prevalence of preterm neonates and risk factors. Iran J Neonatol. 2011;2(2):38-42.

18. Ali J, Borah S, Barkataki D, Imsong N. Association of bacterial vaginosis with preterm labour. Indian J Obgyn. 2015;2(2):93-7.

19. Jain DR. Role of bacterial vaginosis in preterm labor a prospective study. Int $\mathrm{J}$ Med Res Rev. 2016;4(4):543-9.

20. Seth R, Maheshwari M, Saini L, Sharma V. Effects of bacterial vaginosis on perinatal outcome. J Evol Med Dent Sci. 2014;3(8):2040-6.

21. Henderson J, Carson C, Redshaw M. Impact of preterm birth on maternal well- being and women's perceptions of their baby: a population-based survey. BMJ Open. 2016;6(10).

22. Uma $S$, Nisha $S$, Shikha $S$. A prospective analysis of etiology and outcome of preterm labor. Obstet Gynecol. 2007;57(1):48-52.

23. Ali J, Borah S, Barkataki D, Imsong N. Association of bacterial vaginosis with preterm labour. Indian J Obgyn. 2015;2(2):93-7.

24. Subtil D, Denoit V, Gouëff FL, Husson MO, Trivier $\mathrm{D}$, Puech F. The role of bacterial vaginosis in preterm labor and preterm birth: a case-control study. Eur J Obstet Gynecol Reprod Biol. 2002;101(1):416.

25. Bangal VB, Shinde KK, Khanvelkar GK, Patil NA. A study of risk factors and perinatal outcome in preterm labour at tertiary care hospital. Int J Biomed Res. 2012;3(3):87-9.

Cite this article as: Lewis PF, Kumari A, Bavdekar N. Maternal outcome in preterm labor in a tertiary care hospital. Int J Reprod Contracept Obstet Gynecol 2021;10:222-7. 